\title{
Factors that Influence to Intention to Use Electronic Money by UTAUT Model Approach
}

\author{
Nihayatu Aslamatis Solekah ${ }^{1 *}$, Teguh Wildan Hilmawan ${ }^{2}$ \\ ${ }^{12}$ Universitas Islam Negeri Maulana Malik Ibrahim Malang, Indonesia \\ *Corresponding author._Email: aslamatiss_1@pbs.uin-malang.ac.id
}

\begin{abstract}
The purpose of this study was to determine antecedent Intention to Use Electronic Money with UTAUT model approach. This research uses descriptive quantitative method. Data were collected as many as 152 respondents. The sample in this study was 152 respondents by using purposive sampling of Malang city society who were over 13 years old and wanted or had used electronic money. Data analysis by structural model assessment with the Partial Least Square (PLS) analysis method. The results indicated that UTAUT model that consists of performance expectancy, effort expectancy, social influence and behavioral intention had positive influence on the intention of Malang society to use electronic money. These result implications for the government and service provider companies to always develop better innovations in the administration of electronic money by adding facilities that could be enjoyed by users when using electronic money.
\end{abstract}

Keywords: Performance expectancy, effort expectancy, social influence, facilitating conditions, behavioral intention, use behavior, electronic Money

\section{INTRODUCTION}

According to data published by Bank Indonesia from 2009 to 2019 there are 38 electronic money issuers registered at Bank Indonesia, both from banking companies and telecommunications companies. It is estimated that each year will increase according to the increasing needs of the society. The development of the electronic money use continues to increase from year to year, even though it had decreased in the periods of 2014 and 2015 , but in 2016 there was increase of $49.22 \%$ to $51,204,580$ the amount of electronic money circulating in the public. Then in the following years it continued to increase until the latest data from Bank Indonesia in June 2019 , electronic money in circulation was $209,891,847$. With the increase in the number of electronics in circulation, this indicates that the public is increasingly aware of the benefits of using electronic money and accepting electronic money as a means of payment for daily activities. The transaction volume and transaction nominal from the use of electronic money each year always increase simultaneously. The most significant increase in volume was in 2018 of 1,979,378,972 or $209.83 \%$ and nominal value of $34,823,147$ or $281.38 \%$ from the previous year. In line with the increasing volume and nominal value of transactions from the use of electronic money, so did the number of reader machines as a medium for connecting users and merchants to make transactions. This shows that the public is very enthusiastic about and supports the use of electronic money as a means of payment to replace cash in order to support government policies to form a cashless society [1].

Previous research attempts to examine the factors that influence the use of information technology. Venkatesh et. al [2] conducted research on the Unified Theory of Acceptance and Use of Technology (UTAUT). The study is conducted to combine several information technology acceptance models and to hypothesize that performance expectancy, effort expectancy, and social factors have an influence on the intention in the use of information technology, while the facilitating conditions and intention in utilization have influence on the use of information technology. The result states that there is significant positive relationship between effort expectancy, performance expectancy, and social influences on intention in the use of information technology. On the other hand, facilitating conditions and intention in utilization also have significant positive influence on the use of information technology [2].

Research examines the factors that influence acceptance intention and use behavior in Information Systems [3]. The result is that there is significant positive influence of effort expectancy and facilitating conditions the intention in acceptance and use of SI and intention in 
acceptance has an influence on the use of SI. Meanwhile, performance expectancy and social factors do not influence the intention in the acceptance and use of Information Systems. This is inversely proportional to research [4] which examines the factors that influence intention in the use and use of Accounting Information Systems. The result is that performance expectancy, effort expectancy, social influences have significant positive influence on intention in using AIS and facilitating conditions positive influence on the use of AIS. Despite the fact that the widespread replication, application and integration of UTAUT has allowed many researchers to understand technology adoption, it is still necessary to systematically investigate and theorize about the important factors that apply to the use of context-based consumer technology [5]. In fact, there is much debate among researchers, for review, see [5] who argue that the UTAUT construction may not be sufficient to explain the acceptance of new technology users in voluntary context as UTAUT's initial study focused on large organizations in business environment. limit its explanatory power.

Based on the background that the author has described, the authors are intentioned in conducting research on the Factors That Influence the Intention of Malang City Society in Using Electronic Money. This study aims to determine the influence of performance expectancy, effort expectancy, social influences on behavioral intention in Malang city society using electronic money and to determine the influence of facilitating conditions and behavioral intention on the behavior of electronic money use in Malang city society.

This study aims to examine the use of information technology with the object of electronic money using the UTAUT model to find out how much influence performance expectancy, effort expectancy, and social influences have on the intention in using electronic money then the facilitating conditions and use intention of electronic money.

\subsection{Research Hypothesis}

\subsubsection{Performance Expectancy (PE) affect the Behavioral intention to use Electronic Money (BIUEM)}

Performance Expectancy is defined as the level at which a person believes that using the system will help that person to obtain performance benefits at work [2]. Behavioral intention has strong role in shaping the use of technology or system [2]. Research conducted by Kirana [6] identifies that performance expectancy have influence on the use of information systems. Performance expectancy have influence on the behavioral intention in technology use [2]. Based on this description, the following research hypothesis is proposed:

H1: Performance expectancy have positive influence on behavioral intention to use electronic money.

\subsubsection{Effort Expectancy (EE) affect the Behavioral Intention to use Electronic Money (BIUEM)}

Expectancy is the ease level of the system use which will reduce the effort (effort and time) of individuals in doing their jobs [2]. Victor [3] identifies positive and significant influence of effort expectancy on the behavioral intention in using information systems. This is in accordance with the theory of Venkatesh, [2] which states that performance expectancy have influence on the behavioral intention in using information systems. Then the research hypothesis is proposed as follows:

$\mathrm{H} 2$ : Effort expectancy have positive influence on intention to use electronic money.

\subsubsection{Social Influence (SI) affect the Behavioral intention to Use Electronic Money (BIUEM)}

Social influence as the degree to which individual considers the people around him such as family or friends inviting the individual to use the new system[2]. The research suggested that social influence has significant influence on the behavioral intention in using technology[7]. This is the same as research which states that social influence has positive influence on behavioral intention [11]. Therefore, the following hypothesis is proposed:

H3: Social influence has positive influence on the intention in using electronic money.

\subsubsection{Facilitating Conditions (FC) affect Use Behavior on Electronic Money (UBEM)}

The facilitating conditions of the information systems use is the level at which a person believes that the organizational and technical infrastructure exists to support system use[4]. the influence of facilitating conditions has positive influence on the use of information technology [8]. Facilitating conditions have significant influence on the use of information systems [4]. Then the hypothesis is proposed as follows:

H4: Facilitating conditions has positive influence use behavior on Electronic Money

\subsubsection{Behavioral intention to Use Electronic Money (BIUEM) affect Use Behavior on Electronic Money (UBEM)}


Intention is the desire to perform behavior. Intention is not yet in the form of behavior[9]. Behavior is real action or activity that is carried out. In this study, behavioral intention is used to determine how much public intention in using electronic money is. The research shows that behavioral intention has significant influence on use behavior[10]. Therefore, the following research hypothesis is proposed:

H5: behavioral intention on electronic money has positive influence to use behavior

The conceptual framework model in this study uses independent variables, namely: performance expectancy, effort expectancy, social influences, and facilitating conditions. While the dependent variables in this study, namely: behavioral intention and use behaviour.

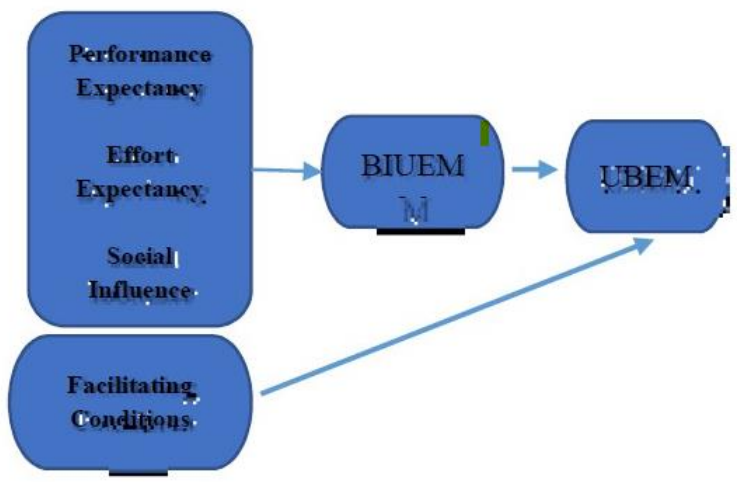

Figure 1 Conceptual framework

\section{METHODS}

The technique used in this research was purposive sampling in which the sampling was selected based on certain criteria that have been set by the researcher. These criteria include: (1) People who live and live in Malang city, (2) age > 13 years old, (3) have insight into electronic money and (4) already have/use electronic money. The sample in this study was 152 respondents by using purposive sampling of Malang city society who were over 13 years old and wanted or had used electronic money. Data analysis in this study used Partial Least Square (PLS) approach with measurement model (Outer Model) and structural model (Inner Model). The measurement model (Outer Model) consisted of validity test with validity scale divided into two, namely convergent validation and discriminant validation [13]. While the structural model (Inner Model) was evaluated using the R2 value for the dependent construct, the path coefficient value or evaluates for each path to test the significance between constructs in the structural model.

\section{RESULTS AND DISCUSSION}

\subsection{Convergent Validity}

The convergent validity has been checked first in the finding section and the statistics show that high correlation among items and valid convergent validity. The results show that Alpha and CR are larger than 0.70 while loadings and AVE are more than 0.50. These values are shown in Table 1 and Figure 2.

Table 1 Convergent validity.

\begin{tabular}{|c|c|c|c|c|}
\hline PE1 & 0.804 & 0.770 & 0.867 & 0.685 \\
\hline PE2 & 0.822 & & & \\
\hline PE3 & 0.822 & & & \\
\hline EE1 & 0.764 & 0.855 & 0.902 & 0.697 \\
\hline EE2 & 0.704 & & & \\
\hline EE3 & 0.725 & & & \\
\hline EE4 & 0.718 & & & \\
\hline SI1 & 0.764 & 0.716 & 0.818 & 0.530 \\
\hline SI2 & 0.704 & & & \\
\hline SI3 & 0.725 & & & \\
\hline SI4 & 0.718 & & & \\
\hline FC1 & 0.798 & 0.761 & 0.863 & 0.677 \\
\hline FC2 & 0.844 & & & \\
\hline FC3 & 0.826 & & & \\
\hline BIUEM1 & 0.911 & 0.910 & 0.944 & 0.848 \\
\hline BIUEM2 & 0.910 & & & \\
\hline BIUEM3 & 0.942 & & & \\
\hline UBEM1 & 0.752 & 0.873 & 0.914 & 0.727 \\
\hline UBEM2 & 0.928 & & & \\
\hline UBEM3 & 0.853 & & & \\
\hline UBEM4 & 0.869 & & & \\
\hline
\end{tabular}




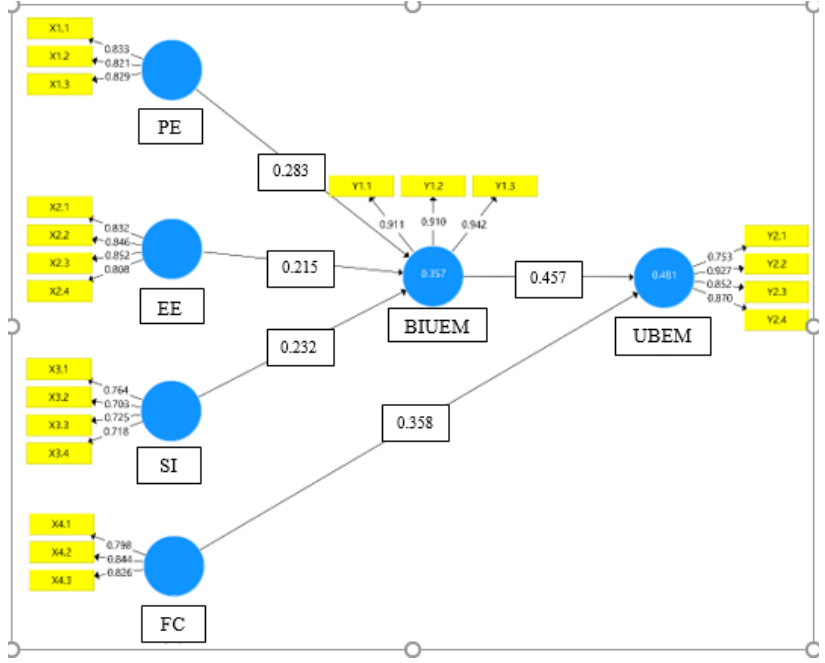

Figure 2 Measurement model assessment

Based on the results of the test after elimination as shown in Figure 2, it can be interpreted that the outer loading value of all instruments is above 0.70 as well as the composite reliability value and Cronbach's alpha and the AVE value which is already above 0.50 . So, all instruments in this study were said to be valid and reliable. For the measurement model test (Outer Loading) can use the convergent validity test and discriminant validity.

Convergent validity of the measurement model with the reflection indicator could be seen from the correlation between the indicator value and the construct value. The construct indicator is said to be valid if it had correlation value above 0.70 [12]. Following were the results of the correlation between the indicators and their constructs, it could be seen in table 1 the value of cross loading. Based on the table, it shows that the outer loading (cross loading) value is in accordance with the requirements, which was above 0.70 . Overall, it could be concluded that the construct had good convergent validity.

The discriminant validity of the reflection indicator could be seen in the cross-loading value between the indicator and its construct and the measure of different constructs should not be highly correlated. How to test discriminant validity by seeing whether the cross-loading value for each construct should be above 0.70 [12].

\subsection{Hypothesis test}

The result of path coefficient is to see the significance of the influence between variables. The results of the bootstrapping data processing are presented in the following table 2 and figure 3 :
Table 2 result of path coefficient

\begin{tabular}{|l|l|l|l|l|}
\hline Relationships & Beta & S.D. & t-statistics & p-values \\
\hline PE ->BIUEM & 0.283 & 0.103 & 2.762 & 0.006 \\
\hline EE ->BIUEM & 0.215 & 0.094 & 2.281 & 0.023 \\
\hline SI -> BIUEM & 0.232 & 0.083 & 2.806 & 0.005 \\
\hline FC -> UBEM & 0.358 & 0.075 & 4.794 & 0,000 \\
\hline BIUEM -> UBEM & 0.457 & 0.074 & 6.194 & 0,000 \\
\hline
\end{tabular}

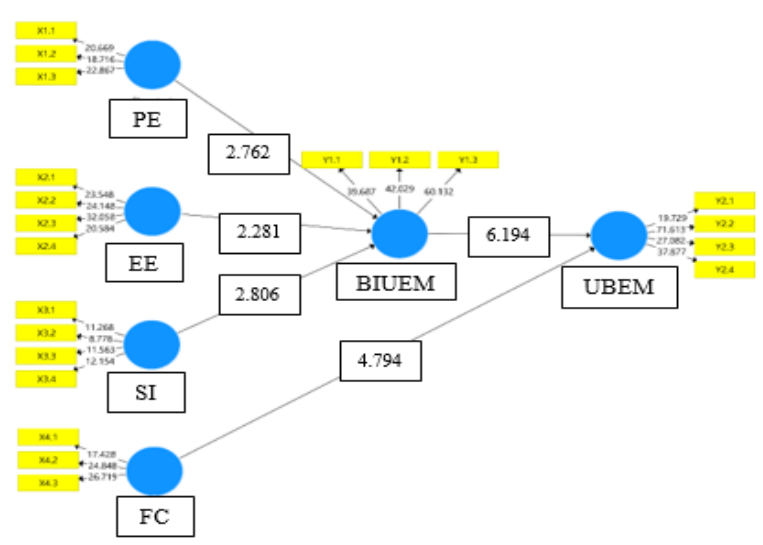

Figure 3 sructural model assessment

The results in table 2 can be interpreted by looking at the original sample value to determine the relationship between the variables studied. Furthermore, to determine the level of significance of the influence of the relationship between variables can be seen in the $\mathrm{T}$ Statistic. In this study, using a significant level of 5\% with true confidence level of $95 \%$ so that the t-table result is 1.976 . If the T-statistic value> T-table, the results are significant.

From the path coefficients showed that the influence of performance expectancy on the behavior intention in using electronic money had original sample value of 0.283 , this value indicated that this variable had positive influence. On the other hand, the results and the t-statistic value were 2,791>1,976, so they showed significant results. Based on these results, the $\mathrm{H} 1$ hypothesis in this study was accepted because performance expectancy had positive influence on the behavioral intention in using electronic money.

These results could be interpreted that the higher the performance expectancy, the higher the intention of Malang society to use electronic money. This could be assessed because the Malang society feel that electronic money is useful in their lives, they feel that using electronic money could increase productivity, then using electronic money allows them. Based on the test results 
for the first hypothesis can be interpreted that the higher the performance expectancy, the higher the intention of Malang society to use electronic money. This can be assessed because the Malang society feel that electronic money is useful in their lives, they feel that using electronic money could increase productivity, then using electronic money allowed them to complete activities faster and if they use electronic money it would increase the chance of earn extra. This is in accordance with research conducted which states that performance expectancy variables have positive influence on behavioral intention [6]. Performance expectancy are defined as the level at which someone believes that using the system would help that person to obtain performance benefits on the job [2]. This research supported previous research that showed that individuals were more likely to use electronic money because they believed using electronic money can be beneficial in life, increase work productivity, help work faster, increase job effectiveness and earn extra.

The second hypothesis test results effort expectancy had positive influence on the intention in using electronic money. These results can be interpreted that the higher the effort expectancy, the higher the intention of Malang society to use electronic money. This was because Malang society feels that using electronic money was clear and understandable, it was easy for them to be skilled in using electronic money, then they find electronic money easy to use and learning to operate electronic money was easy for them. Effort expectancy is the level of ease of use of the system which could reduce the effort (effort and time) of individuals in doing their jobs [2]. The results of this study were different from research which showed that effort expectancy did not affect the intention in using technology [7]. This difference may be due to geographic factors of research and local culture. In an Islamic perspective, there was also a verse that explains effort expectancy (convenience), namely in the letter Al Baqarah verse 185:

Meaning: "Allah intends for you ease and does not intend for you hardship (Q.S. Al Baqarah:185)"

Allah has provided various conveniences in doing everything for any purpose and purpose. One of them was to ensure that humans could run something effortlessly in terms of the dimensions of space and time and also to encourage/motivate people to be diligent and enthusiastic about carrying out a job because it can be done easily and without difficulty.

The results of the third hypothesis test show that social influence had positive influence on the intention in using electronic money. These results could be interpreted that the higher the social influence, the higher the intention of Malang society to use electronic money. This was because people who influence their behavior encourage them to use electronic money, people who are important to them require them to use electronic money than their friends/family help in using electronic money and in general their environment supports using electronic money. The results of this study supported the research on the use of internet banking in Lebanon [2] [7] and [11] on the use of internet banking at Bank BNI. In short, it could be concluded that the Malang society use electronic money because of the influence of their friends, relatives or family. When customers felt satisfaction using electronic money, it would influence other people around them to use electronic money too.

The results of the fourth hypothesis could be interpreted that the higher the conditions that facilitate the higher intention of Malang people in using electronic money. This was because people in Malang city had the necessary resources to use electronic money, they had the necessary knowledge to use electronic money, then they were sure that electronic money was compatible with other systems they use and they could get help from other people when they had difficulty using electronic money. These results also proved that the people of Malang had knowledge or insight that could help users to use electronic money. In addition, the supporting conditions were also indicated by the availability of electronic money media, which means that users already had electronic money card or smartphone so that consumers could install the electronic money application. On the other hand, the government also encouraged the use of electronic money by providing supporting facilities such as payments on toll roads. This result supported previous research on the e-ticket system[8], on the use of accounting information systems [4]. The supporting condition was the level at which individuals believe that an organization and infrastructure support the use of the system [2]. Therefore, it could be concluded that the existence of supporting conditions indeed encouraged the people of Malang to use electronic money. Electronic money companies should expand their cooperation with merchants so that people could use electronic money anywhere and anytime.

The fifth hypothesis test results could be interpreted that the higher the behavioral intention, the higher the intention of Malang society to use electronic money. This was because Malang society intended to use electronic money in the future and predicted that they would use electronic money and they planned to use electronic money in the future. According to Kotler [14] intention was something that arises after receiving stimulation from the product he sees, then intention arises to try the product and finally the desire to buy and be able to own the product arises. The results of this study support previous research [10];[15] which showed that behavioral intention influences the behavior of using technology. Therefore, it could be concluded that the behavioral intention factor encourages Malang society to use electronic money. 


\section{CONCLUSION}

The factors that influenced the intention of Malang society to use electronic money based on the results of data analysis and the discussion that have been described could be concluded as follows: The performance expectancy variable had positive influence on the intention of Malang society to use electronic money. This was because performance expectancy could influence the individual to use electronic money.

The effort expectancy variable had positive influence on the intention of Malang society to use electronic money, this was because the system for using electronic money was easy to use so that it could be understood, practically as means of payment.

The social influence variable had positive influence on the intention of Malang society to use electronic money, this was because there is influence from friends or family. This condition attracted other and affected people to try to use electronic money. Facilitating condition variables had positive influence on the use behavior of electronic money. This meant that Malang society would be intentioned in using electronic money if there were supporting facilities from the government or electronic money service providers or facilities created by consumers such as having internet network or a smartphone.

The behavioral intention variable had positive influence on the use behavior of electronic money. It could be concluded that there was factor of behavioral intention that encouraged Malang society to use electronic money.

The implication of the results of this study was that the stakeholders of electronic money service providers were expected to continue to develop better innovations in electronic money administration by adding facilities that could be enjoyed by users when using electronic money.

In addition, from the results of this study, electronic money service providers should continue to strive to add electronic money service support facilities so that their network use was wider and easier to access.

\section{REFERENCES}

[1] Bank Indonesia, accessed 20 Agustus 2019 retrieved from https://www.bi.go.id/id/sistempembayaran/informasi-perizinan/uangelektronik/penyelenggaraberizin/Pages/default.aspx.

[2] V. Venkatesh, M.G. Morris, G.B. Davis, and F.D. Davis, "User acceptance of information technology: toward a unified view”, MIS Quarterly, 27(3) 2003 $425-478$

[3] V. Hendrik, Analisis Faktor-faktor Yang Mempengaruhi Minat Penerimaan dan Perilaku Penggunaan Sistem Informasi. (Skripsi). Semarang: Fakultas Ekonomika dan Bisnis Universitas Diponegoro, 2016

[4] S. Suhartini, Analisis Faktor-faktor yang Mempengaruhi Minat Pemanfaatan dan Penggunaan Sistem Informasi Akuntansi (Studi Kasus pada Bank Syariah Mandiri Malang). (Skripsi). Malang: Fakultas Ekonomi Universitas Islam Negeri (UIN) Maulana Malik Ibrahim, 2017

[5] V. Venkatesh, J. Thong, and X. Xu, "Consumer acceptance and use of information technology: extending the unified theory of acceptance and use of technology", MIS Quarterly, 36(1) 2012 157-178, DOI: https://doi.org/10.2307/41410412.

[6] N. Kirana, Analisis Faktor-faktor Yang Mempengaruhi Minat Penggunaan Sistem Informasi Berbasis Komputer Dengan Model UTAUT (Studi Empiris pada Pengguna Sistem Informasi Akuntansi di Bank Mandiri). (Skripsi). Semarang: Fakultas Ekonomika dan Bisnis Universitas Diponegoro, 2016

[7] A. Tarhini, M. El-Masri, M. Ali, A. Serrano, "Extending the UTAUT model to understand the customers' acceptance and use of internet banking in Lebanon A structural equation modeling approach", Information Technology \& People, 29(4) 2016 830-849, DOI: 10.1108/ITP-02-20140034 .

[8] N. J. Jati and H. Laksito, "Analisis Faktor-faktor yang Mempengaruhi Minat Pemanfaatan dan Penggunaan Sistem E-Learning”. Diponegoro Journal of Accounting, 1(2) 2012

[9] F. D. Davis, F. D., "Perceived Usefulness, Perceived Ease of Use, and User Acceptance of Information Technology”, MIS Quarterly, 13(3) 1989 319-340, DOI: https://doi.org/10.2307/249008.

[10] A. Fauzi, T. Widodo, and T. Djatmiko, "Pengaruh Behavioral Intention Terhadap Use Behavior Pada Penggunaan Aplikasi Transportasi Online (Studi Kasus Pada Pengguna Go-Jek Dan Grab di Kalangan Mahasiswa Telkom University)," EProceeding of Management, 5(2) 2018.

[11] R. Cristiani, (2018). Analisis Pengaruh Performance Expectancy, Effort Expentancy, Social Influence dan Facilitating Condition Terhadap Behavior Intention Dengan Dimoderasi Oleh Usia Pada Nasabah Bank BNI Cabang Graha Pangeran 
Surabaya. (Tesis). Surabaya: Program Magister Manajemen Universitas Katolik Widya Mandala, 2018

[12] I. Ghozali, and H. Latan, "Partial Least Squares; Konsep,Teknik dan Aplikasi Menggunakan ProgramSmartPLS 3.0", Semarang: Badan Penerbit Undip, 2015

[13] J. F. Hair, C. M. Ringle, \& M. Sarstedt, "PLS-SEM: Indeed a Silver Bullet”, The Journal of Marketing Theory and Practice, 19(2) 2011 139-152.
[14] P. Kotler, and K. L. Keller, Manajemen Pemasaran, Edisi 14, Jilid 1. Jakarta: PT. Indeks, 2012

[15] C. Makanyeza, S. Mutambayashata, "Consumer's Acceptance and Use of Plastic Money in Harare, Zimbabwe (Application of the Unified Theory of Acceptance and Use of Technology 2)", International Journal of Bank Marketing, 36(2) 2017 379-392, DOI: https://doi.org/10.1108/IJBM-032017-0044 